\title{
Adaptação da respirometria como ferramenta para predizer a cinética da decomposição anaeróbia e a produção de $\mathrm{CO} 2$ de efluente de abatedouro de bovinos
}

\section{Thomas S. Figueiredo*, Paulo Eduardo S. Soldera, Enelton Fagnani.}

\section{Resumo}

Dada as características intrínsecas dos efluentes provenientes do abate de bovinos, utiliza-se frequentemente em seu tratamento processos anaeróbios, sendo o mais empregado o sistema de lagoas em série. Atualmente, a concepção destes sistemas segue critérios baseados na tratabilidade de esgotos domésticos, sem equacionamento específico. $\mathrm{O}$ presente trabalho estuda a biodegradabilidade do efluente de abate submetido a processo anaeróbio, subsidiando estudos mais específicos e visando a concepção de plantas mais eficientes no seu tratamento.

\section{Palavras-chave:}

Respirometria de Bartha, Degradação anaeróbia, Temperatura.

\section{Introdução}

Devido aos elevados níveis de Demanda Bioquímica de Oxigênio (DBO) e Demanda Química de Oxigênio (DQO), o efluente de abatedouros tem a capacidade de gerar graves problemas se incorporar ao volume de esgoto municipal sem haver recebido um tratamento adequado. (MATA-ALVAREZ; MACÉ; LLABRÉS, 2000). A digestão anaeróbia é viável para o tratamento destes efluentes, já que o processo apresenta uma alta remoção carga orgânica, pequena produção de lodo, baixo consumo de energia e possível reaproveitamento de biogás (CHAN et al., 2009). Dado que a temperatura é um fator fundamental no tratamento (FENG et al., 2018), o trabalho tem como objetivo apresentar um modelo pratico de avaliar o comportamento cinético da degradação anaeróbia de efluentes de abatedouro em diferentes condições de temperatura.

\section{Redução de DQO}

\section{Resultados e Discussão}

Foram realizadas amostras de $D Q O$ e $D B O$ comcomitaneamente às análises de respirometria, obtendo-se assim um comportamento da remoção de DQO em função do tempo de permanência para diferentes temperaturas.

Figura 1 -Remoção de DQO em função do tempo de permanência.

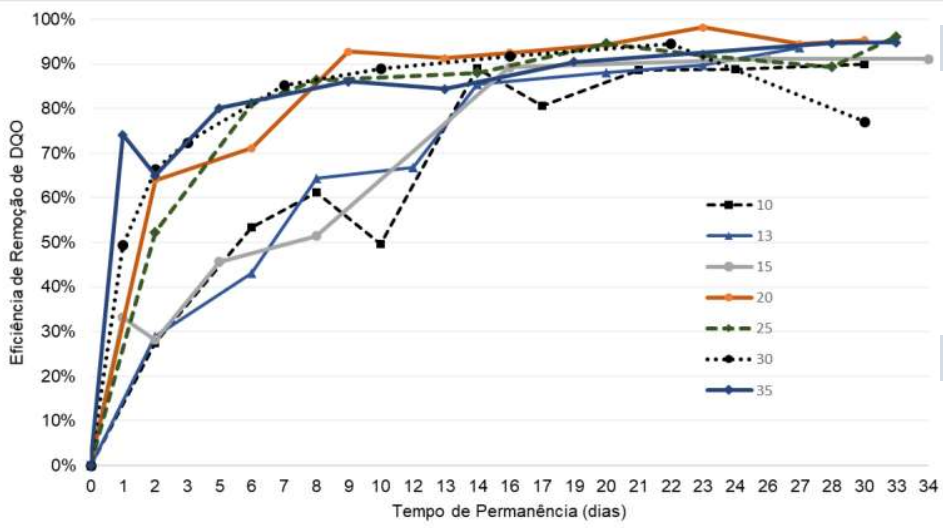

Reiterando FENG et al., (2018), obteve-se um processo mais estável e mais eficiente na faixa mesófila entre 25 e $45^{\circ} \mathrm{C}$. Após 16 dias acumulados, todas curvas atingiram $90 \%$ de remoção (Figura 1).

\section{Emissão de $\mathrm{CO}_{2}$}

Empregou-se uma otimização de tecnologia analítica adaptando-se o método de Bartha convencional (BARTHA; PRAMER, 1965) para respirometria em amostra líquida em condições anaeróbias. O rendimento de $\mathrm{CO}_{2}$ foi calculado em função da DQO inicial.

Figura 2 - Rendimento de produção de $\mathrm{CO}_{2}$ em função do tempo

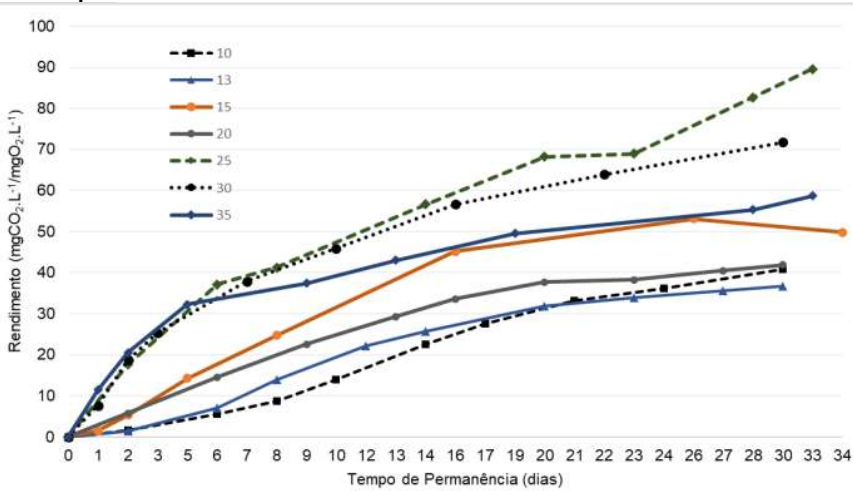

Verificou-se que a emissão de $\mathrm{CO}_{2}$ apresenta diferentes comportamentos de acordo com a temperatura, constatando maior eficiência entra as temperaturas de 25 e $30^{\circ} \mathrm{C}$ (Figura 2). Esta emissão esta relacionada com a redução da carga orgânica no liquido em função da temperatura (FAGNANI; SOLDERA; SPIEWAK, 2019).

\section{Conclusões}

Os resultados obtidos indicam que é possível utilizar a adaptação do método de respirometria de Bartha para efluentes como uma ferramenta efetiva para investigar a degradação anaeróbia através da medição de emissão de $\mathrm{CO}_{2}$ e correlacionar com a redução de carga orgânica no líquido.

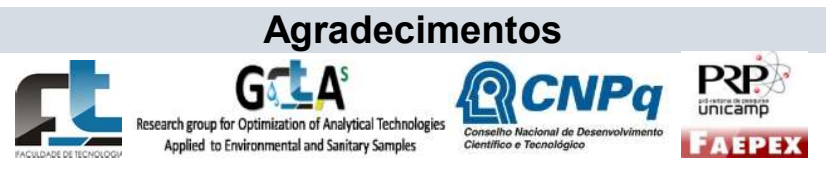

${ }^{1}$ BARTHA, R.; PRAMER, D. Soil Science, v. 100 n. 1, n. 1, p. 68- 70p, 1965. ${ }^{2}$ CHAN, Y. J. et al. Chem. Eng. J. , v. 155, n. 1-2, p. 1-18, 2009.

3FAGNANI; SOLDERA; SPIEWAK, 2019. Rev. DAE, 2019. (no prelo)

${ }^{4}$ FENG, Q. et al. Int. J. H. E. , p. 1-10, 2018.

5MATA-ALVAREZ, J.; MACÉ, S.; LLABRÉS, P. Bio. T., v. 74, n. 1, p. 3-16, 2000. 